\title{
Adult stem cells: hopes and hypes of regenerative medicine*
}

\author{
Józef Dulak ${ }^{\bowtie}$, Krzysztof Szade, Agata Szade, Witold Nowak and Alicja Józkowicz \\ Department of Medical Biotechnology, Faculty of Biochemistry, Biophysics and Biotechnology, Jagiellonian University, Kraków, Poland
}

\begin{abstract}
Stem cells are self-renewing cells that can differentiate into specialized cell type(s). Pluripotent stem cells, i.e. embryonic stem cells (ESC) or induced pluripotent stem cells (iPSC) differentiate into cells of all three embryonic lineages. Multipotent stem cells, like hematopoietic stem cells (HSC), can develop into multiple specialized cells in a specific tissue. Unipotent cells differentiate only into one cell type, like e.g. satellite cells of skeletal muscle. There are many examples of successful clinical applications of stem cells. Over million patients worldwide have benefited from bone marrow transplantations performed for treatment of leukemias, anemias or immunodeficiencies. Skin stem cells are used to heal severe burns, while limbal stem cells can regenerate the damaged cornea. Pluripotent stem cells, especially the patient-specific iPSC, have a tremendous therapeutic potential, but their clinical application will require overcoming numerous drawbacks. Therefore, the use of adult stem cells, which are multipotent or unipotent, can be at present a more achievable strategy. Noteworthy, some studies ascribed particular adult stem cells as pluripotent. However, despite efforts, the postulated pluripotency of such events like "spore-like cells", "very small embryonic-like stem cells" or "multipotent adult progenitor cells" have not been confirmed in stringent independent studies. Also plasticity of the bone marrow-derived cells which were suggested to differentiate e.g. into cardiomyocytes, has not been positively verified, and their therapeutic effect, if observed, results rather from the paracrine activity. Here we discuss the examples of recent studies on adult stem cells in the light of current understanding of stem cell biology.
\end{abstract}

Key words: embryonic stem cells, induced pluripotent stem cells, myocardial infarction, very small embryonic-like stem cells, heme oxygenase-1

Received: 07 April, 2015; revised: 26 April, 2015; accepted: 02 May, 2015; available on-line: 22 July, 2015

\section{DEFINITION OF STEM AND PROGENITOR CELL}

Stem cell is an undifferentiated cell, which can selfrenew to replicate itself as well as give rise to the specialized cells under appropriate conditions (Weissman, 2000). Progenitor cell lacks the self-renewal capability and often is unipotent - differentiates into only one cell type.

There are distinct kinds of stem cells according to their differentiation potential. Multipotent stem cells can differentiate into many cell types, but within a particular lineage. For example, the hematopoietic stem cells (HSC) can develop into red blood cells, white blood cells and platelets. Pluripotent stem cells are capable of giving rise to all cells of all tissue types (Jaenisch \& Young, 2008).
The examples of pluripotent stem cell are embryonic stem cells (ESC) and induced pluripotent stem cells (iPSC) (Takahashi \& Yamanaka, 2006).

Adult stem cells, which exist in the postnatal organism, are either multipotent or unipotent (Wagers \& Weissman, 2004). The majority of known adult stem cells reside in the bone marrow. Among them are the multipotent HSC which have a capacity to regenerate the entire hematopoietic system (Bryder et al., 2006). Accordingly, therapeutic bone marrow transplantation has been used for more than 30 years, and more than million patients suffering from different blood diseases have already been treated with transplantation of the BM or the mobilized BM-derived cells. The other adult stem cells that reside in the bone marrow are the mesenchymal stem cells, defined also as the mesenchymal stromal cells (MSC), which can differentiate into the bone, chondrocytes and adipose cells (Bianco, 2014) (Fig. 1).

\section{IN THE SEARCH FOR PLURIPOTENT ADULT STEM CELL}

Multipotent or unipotent differentiation potential of adult bone marrow stem cells, like HSC or MSC, are very well known. Nevertheless, from time to time, it is claimed that the bone marrow cells can give rise to the cells of various organs and can differentiate not only into the blood or to the bone, but also to the blood vessels (Asahara et al., 1999), muscles (Ferrari et al., 1998), cardiomyocytes (Orlic et al., 2001), skin (Kataoka et al., 2003) or even can regenerate the kidney (Kale et al., 2003), pancreas (Hess et al., 2003) and the nervous system (Mezey et al., 2000). What are the scientific rationales and proofs underlying such conclusions?

The vast differentiation potential of the bone marrowderived cells has often been suggested on the basis of experiments performed in cells cultured for the long time in vitro. Indeed, under such conditions, the expression of different markers can be demonstrated in the bone marrow cells. Recently our group has investigated the murine bone marrow-derived mesenchymal cells with CD 45-CD $34^{+} \mathrm{CD} 14^{+}$phenotype (Szade et al., 2011). To isolate this population we cultured plastic adherent bone marrow cells for at least 10 passages. During this longterm culture the cells changed considerably their gene

e-mail: jozef.dulak@uj.edu.pl

*Presented at 42nd Winter School of the Faculty of Biochemistry, Biophysics and Biotechnology of the Jagiellonian University, February 16-21, 2015, Zakopane, Poland.

Abbreviations: $\mathrm{CO}$, carbon monoxide; ESC, embryonic stem cells; GFP, green fluorescent protein; HO-1, Heme oxygenase-1; HSC, hematopoietic stem cells; iPSC, pluripotent stem cells; MAPC, multipotent adult progenitor cells; LAD, left anterior descending; LVEF, left ventricular ejection fraction 


\section{Pluripotent}

\section{Embryonic}

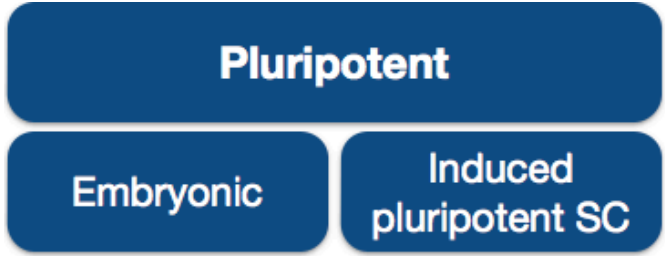

1. Differentiate into cells of all three lineages: ectoderm, mesoderm, endoderm

2. Able to contribute to chimera formation / complement blastocyst

3. Form teratomas pluripotent SC

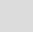

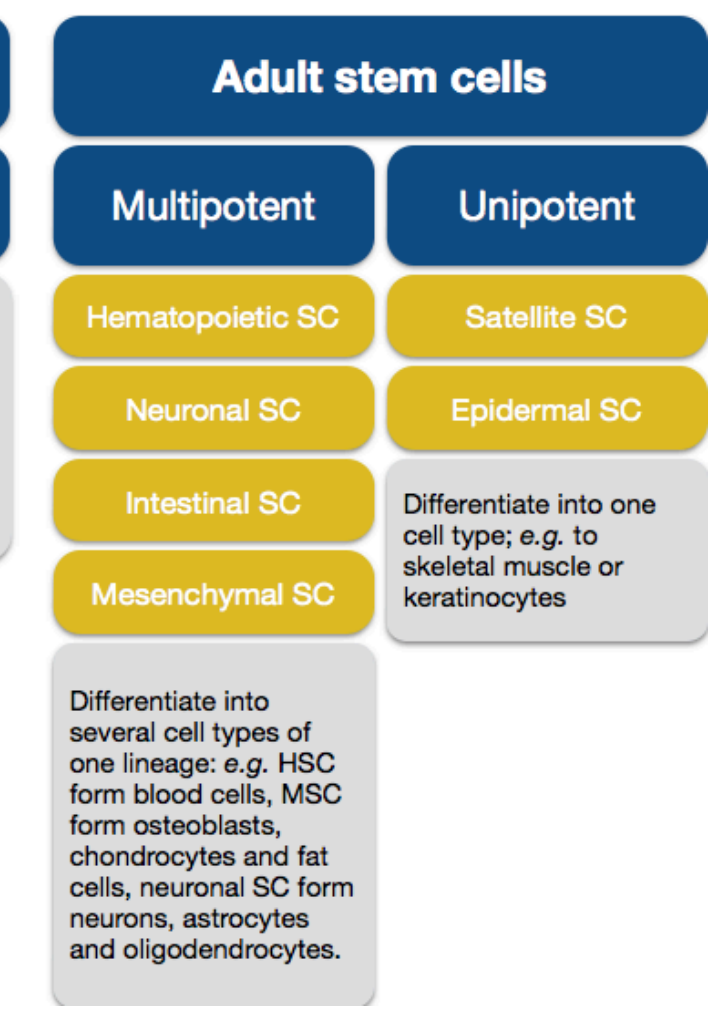

Figure 1. Major properties of stem cells.

Pluripotent stem cells under normal circumstances are not present in the adult organism - they are obtained as the result of isolation of the inner cell mass of the blastocyst (embryonic stem cells) or reprogramming of somatic cells by overexpression of defined transcription factors (induced pluripotent stem cells). Adult stem cells are either multipotent or unipotent. In the same organ, e.g. in the skin, both multipotent and unipotent populations of stem cells can exist.

expression profile (Szade et al., 2011). Such cultured population could differentiate into PPAR $\gamma+$ adipocytes, what reflected the natural propensity of MSC. Under conditions promoting endothelial cell growth, we observed upregulation of endothelial genes and some endothelial function properties, like formation of tube-like structures on Matrigel, lectin binding or upregulation of VCAM-1 after TNF $\alpha$ stimulation. On the other hand, under neuronal differentiation conditions a few cells of this population expressed the neuronal markers (Szade et al., 2011).

Expression of different markers appearing in the in vitro cultures of bone marrow cells is considered as an indication of their vide differentiation potential and makes the rationale for application of such cells for the treatment of various conditions in organs in which the bone marrow cells do not reside naturally. Accordingly, the bone marrow cells have been used in experimental animals for treatment of myocardial infarction (Kamihata et al., 2001; Orlic et al., 2001), hind limb ischemia (Kalka et al., 2000), stroke (Chen et al., 2001), as well as liver (Petersen et al., 1999) or kidney injury (Kale et al., 2003). It has been claimed that the bone marrow cells have the capacity to differentiate into cardiomyocytes (Orlic et al., 2001), endothelial cells (Asahara et al., 1997), neuronal cells (Mezey et al., 2000), hepatocytes (Petersen et al., 1999) or kidney epithelial cells (Kale et al., 2003). Particularly the bone marrow MSC were regarded as cells of versatile properties (Jiang et al., 2002). Soon after the experimental studies, the clinical trials have been initiated.

Heme oxygenase-1 (HO-1), a stress-inducible enzyme degrading heme to carbon monoxide (CO), iron and biliverdin, has been previously demonstrated by us (Dulak et al., 2002; Józkowicz et al., 2003; Grochot-Przeczek et al., 2014) and others (Deramaudt et al., 1998; Bussolati et al., 2004; Lakkisto et al., 2011) to play a protective role in cardiovascular system. The HO-1 activation can be cytoprotective, anti-apoptotic, anti-inflammatory and proangiogenic. HO-1 overexpression in the heart reduces the cardiomyocyte death and fibrosis, improving the myocardial functions and preventing damages caused by the myocardial ischemia. The expression of HO-1 can be diminished under various pathological conditions; hence its upregulation is considered to be of therapeutic benefit (reviewed in Dulak et al., 2008). Accordingly, several studies have previously demonstrated that application of bone marrow-derived mesenchymal cells overexpressing HO-1 improved the function of the ischemic murine heart (Tang et al., 2005). In line with those results we used porcine bone marrow cells for treatment of myocardial infarction in pigs (Wojakowski et al., 2012). To improve the properties of the isolated cells we transduced them with adenoviral vectors harboring HO-1. Control cells were transduced with vectors encoding green fluorescent protein (GFP). In vitro observations showed that the mesenchymal cells engineered to overexpress HO-1 formed better tube-like structures than their GFP expressing counterparts, what might indicate that HO-1 improves their angiogenic capacity (Wojakowski et al., 2012).

Such cells were used in pigs subjected to experimental myocardial infarction caused by occlusion of left anterior descending (LAD) artery by means of the balloon catheter. The cells were injected through the catheter just before the blood flow was restored. Functional properties of the heart were assessed soon after treatment and two weeks later. One of the parameters used to assess the heart performance after myocardial infarction was left 
A
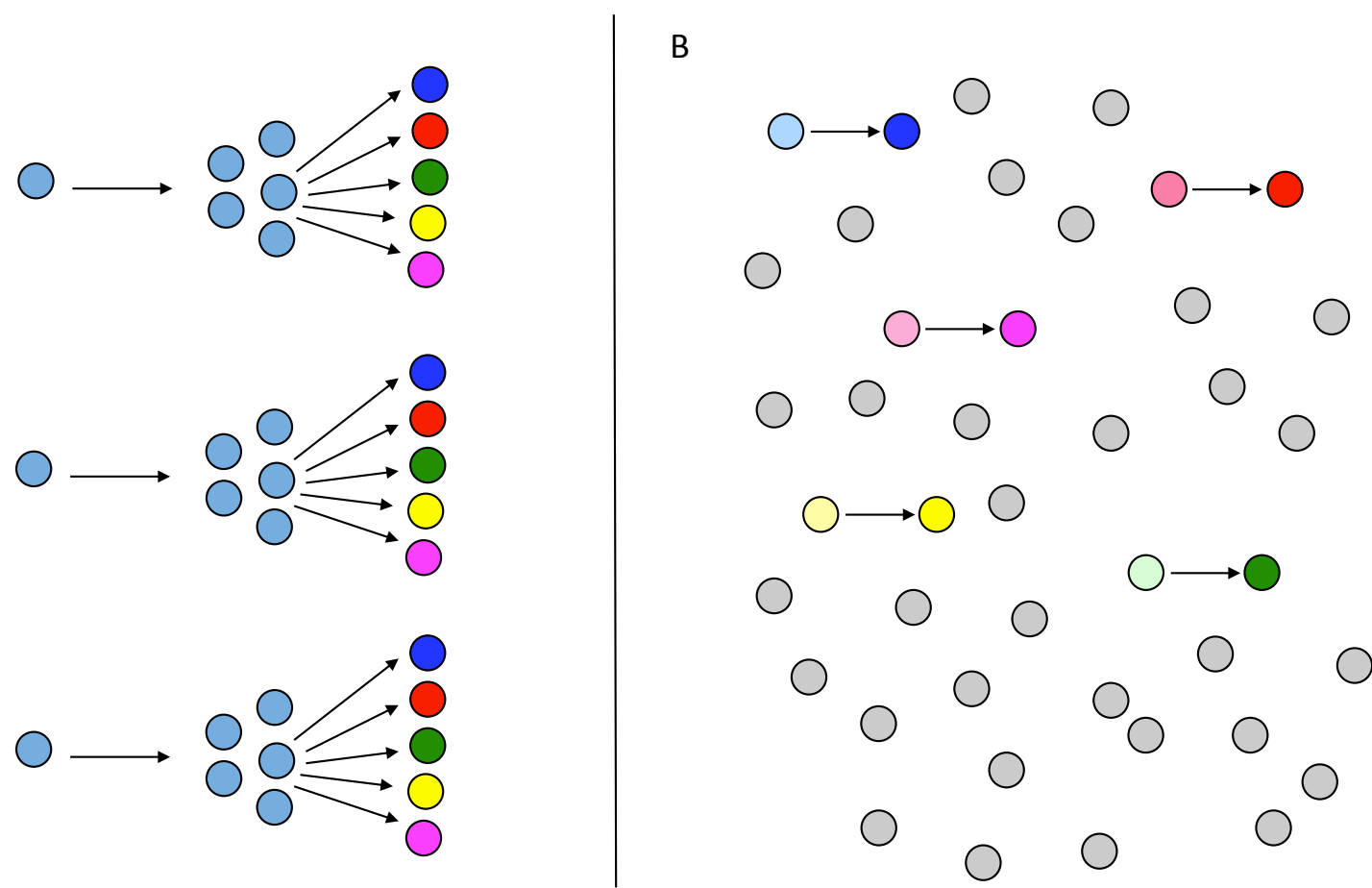

Figure 2. Pluripotent stem cells vs. mixed population of multipotent/unipotent stem cells

(A) Pluripotency has to be always defined by the functional tests. One is the differentiation to various cell types of all three lineages (ectoderm, mesoderm and endoderm), which has to be shown on the single cell level. In this test the clones obtained from single sorted cells of purified population of the cells claimed to be pluripotent are cultured in various conditions allowing their differentiation into multiple cell types. Moreover, additional tests are required to fully confirm pluripotency, namely teratoma formation and blastocyst complementation. Note, however, that chimera formation/complementation of tetraploid blastocyst are not applied to human pluripotent stem cells due to the ethical reasons.

(B) The mixture of the various populations of stem cells, e.g. bone marrow, cannot be interpreted as pluripotent. Such a mixture may contain the cells with limited (unipotent or multipotent potential) which when cultured and differentiated together can make the impression of possessing the properties of pluripotent stem cells.

ventricular ejection fraction (LVEF). Already 30 minutes after administration of cells we observed quite significant increase in LVEF (more than 10\%), but only in those animals which received the mesenchymal cells overexpressing HO-1 (Wojakowski et al., 2012). The LVEF did not improve in animal hearts injected with control cells (Wojakowski et al., 2012).

Undoubtedly, despite the observed beneficial outcome, the effect observed already 30 minutes after cell delivery cannot be interpreted as a result of cell differentiation. Such an influence would require longer time to reveal. Interestingly, after two weeks, all animals which received either the control (GFP expressing) or HO-1 overexpressing cells, showed improved LVEF, however there were no differences between these groups. Nevertheless, this effect can be carefully interpreted as the influence of BM-derived mesenchymal cells on the heart function. Histological analysis of hearts evidenced that there were some GFP or HO-1 overexpressing cells in the infarct border zone, which phenotypically resembled endothelial cells or even cardiomyocytes (Wojakowski et al., 2012).

However, do our studies in murine (Szade et al., 2011) and porcine mesenchymal cells (Wojakowski et al., 2012), as well as numerous other similar observations (for review see: Phinney \& Prockop, 2007) indicate that that those cells are pluripotent and they can differentiate into many cell types, including endothelial cells, neuronal cells or cardiomyocytes?

Such conclusion cannot be drawn, because pluripotency has to be demonstrated at the single cell level
(Fig. 2A). The pluripotent stem cells give rise to different cell types under appropriate conditions. However, the populations of not sufficiently purified cells, like the bone marrow cells, may contain a mixture of unipotent or multipotent stem cells. When we differentiate such heterogeneous population, the various kinds of unipotent stem cells can develop into different mature cells. In such case the appearance of different types of mature cells is not due to the differentiation of pluripotent stem cells, but due to differentiation of unipotent or multipotent stem cells and progenitors (Fig. 2B). Therefore, differentiation potential ascribed to the mixed population of cells (Fig. 2B) must not be confused with differentiation potential of truly pluripotent stem cells (Fig. 2A). To demonstrate the latter, the clones derived from the single sorted cells of putative pluripotent stem cell population have to be cultured under various conditions to demonstrate with sufficiently high statistical incidence the capability to form various types of mature cells (Fig. 2A).

Interpretation of our results should also take into consideration that long-term in vitro culture could artificially affect the differentiation potential of MSC, and therefore any conclusions from in vitro experiments should not be directly extrapolated to in vivo function. Indeed, during the long-term culture the reprogramming events can appear (Li et al., 2007; Tolar et al., 2007; Dahl et al., 2008). Similarly, the expression of tissue-specific markers in cultured cells can result from temporal activation of gene expression and does not point to the functional capacity 
of such cells. For example, MSC-derived cells expressing endothelial cell markers did not exert functional activities of endothelial cells (Kachamakova-Trojanowska et al., manuscript in preparation). Furthermore, the expression of marker genes, used for labeling the injected cells and then detected in different cell types, as we saw in the porcine hearts, can be also explained by cell fusion (Nygren et al., 2004). It has been convincingly demonstrated that the administered cells can fuse with the mature cells in the tissues (Terada et al., 2002; AlvarezDolado et al., 2003; Wang et al., 2003), what results in expression of tags of injected cells, but does not mean that the organ-specific mature cells had developed from the delivered stem cells. Again, in case of heterogeneous cell populations isolated from the bone marrow and injected into various organs, all conclusions concerning multipotent or pluripotent properties have to be driven with a great caution.

The claimed pluripotency of adult stem cells is particularly doubtful. In many reports pluripotency was postulated only on the basis of expression of some marker genes, like Oct-4 or Nanog, and the ability of population of cells, but not single cells, to differentiate into various cell types. The most stringent assays for pluripotency, namely the capacity to form teratomas after the injection into the immunodeficient mice (Müller et al., 2010) and the ability to complement blastocysts (Jaenisch \& Young, 2008) have rarely or never been applied to validate the different types of bone marrow-, cord blood-, or other organ-derived cells regarded by the authors as pluripotent.

\section{THE STORIES OF MAPC, SPORE-LIKE, AND VSEL CELLS}

Despite the limitations and problems associated with ascribing the pluripotency to adult stem cells it is still believed that the dormant pluripotent stem cell populations, with very high therapeutic potential due to the broad differentiation plasticity, do exist in different adult organs.

In 2002 the group of Catherine Verfaillie described the cells they called multipotent adult progenitor cells (MAPC) (Jiang et al., 2002). Those cells, obtained after a very long-term in vitro culture, were able to differentiate into all cell types and even to complement blastocyst (Jiang et al., 2002), what indicated they were really pluripotent. However, this study could not be reproduced by several independent groups (Check, 2007). There were also problems with the same images differentially described in different publications (Baker, 2007).

Another group, led by Charles Vacanti, from Harvard University, has described so-called spore-like cells, which were very small and miraculously resistant to very harsh conditions, like very high or very low temperatures ( Vacanti et al., 2001). Despite the fact that this study has never been reproduced, Dr. Vacanti has claimed that spore-like cells are possibly represented by so-called STAP (stimulus-triggered acquisition of pluripotency) cells, described in 2014 as the pluripotent cells obtained by the short exposure of differentiated cells to the mild acidic conditions (Knoepfler, 2014). As known, the story of STAP cells has ended in very fast retraction of the papers (Obokata et al., 2014a, 2014b), what will be discussed later in this text.

An example of cells whose pluripotency could not be validated by independent groups are so called very small embryonic-like cells (VSELs) described in 2006 by Mariusz Ratajczak and co-workers (Kucia et al., 2006).
Originally, VSELs were recognized as pluripotent on basis of expression of Oct- 4 and other embryonic markers (SSEA-1, Nanog, Rex-1), and were shown to differentiate into cells of all three lineages in vitro (cardiomyocytes, pancreatic and neural cells) (Kucia et al., 2006). They are described as very small events (of diameter of $3.6 \mu \mathrm{m}$ in mice, although the indicated sizes vary), much smaller than hematopoietic stem cells (Zuba-Surma et al., 2009). Further studies performed by the same group showed that VSELs can be differentiated into cells expressing markers of different lineages (Dawn et al., 2008; Huang et al., 2010; Ratajczak et al., 2011a), and their differentiation into hematopoietic stem cells was described (Ratajczak et al., 2011b). Although the freshly isolated VSELs were not able to reconstitute blood of lethally irradiated mice, the authors suggested that the hematopoietic pre-differentiation of VSEL population on OP9 cells can induce their hematopoietic potential (Ratajczak et al., 2011b).

We analyzed the VSELs from murine bone marrow using the initially proposed markers (Kucia et al., 2006): expression of Sca-1, lack of CD45 and lineage antigens (Szade et al., 2013). Such defined population of small cells was still heterogeneous with cell subset expressing also c-Kit, antigen characteristic for hematopoietic lineage. We have characterized these cells, using the stringent approach to investigate the differentiation potential - the single cell assays. We sorted single Lin-CD45Sca-1+c-Kit+ small cells or HSC from murine bone marrow and cultured them under appropriate conditions to determine whether they can differentiate into blood cells. Out of 76 single Lin-CD45-Sca1+c-Kit+ cells we have not seen any colony, whereas $50 \%$ of single HSC formed colonies of hematopoietic cells. Additionally, we performed pre-differentiation of whole VSEL population (Lin-CD45-Sca1+ small cells) on OP9 and then checked their hematopoietic potential, sorting up to 100 cells per well. Again, we observed no colonies, in contrast to HSC. Hence, we did not confirm that murine bone marrow derived VSELs are stem cells with hematopoietic potential (Szade et al., 2013).

Pluripotency of VSELs was postulated owing to expression of Oct-4 (Kucia et al., 2006). Indeed, this gene is expressed in pluripotent stem cells, namely iPS and embryonic stem cells, where its expression is high and demonstrated by whole population. There are several critical issues that have to be considered when analyzing the Oct-4 expression (Liedtke et al., 2008). First, the level of Oct-4 has to be sufficiently high to maintain pluripotency. Second, different variants of Oct-4 exist, which not necessarily are connected to pluripotency (Liedtke et al., 2008). Therefore, it is important to use the correct tools to demonstrate the expression of a proper Oct-4 form, namely Oct$4 \mathrm{~A}$, which is an isoform associated with pluripotency of cells (Liedtke et al., 2007, 2008). Fortunately, various Oct-4 isoforms are relatively easily distinguishable by PCR when using well-designed primers. Oct-4A has E1 exon, which does not exist in another form Oct-4B. Therefore, one can design the primers, which discriminate Oct-4A from Oct-4B. However, in the original paper describing VSELs the primers recognized sequences localized in exons 4 and 5, which are present in both variants of Oct-4 (Kucia et al., 2006). Keeping in mind that it is very difficult or even impossible to distinguish Oct-4A and Oct-4B proteins with antibodies currently available (Liedtke et al., 2007, 2008), no data have convincingly demonstrated that Lin-CD45-Sca1+ cells express Oct-4A. 
We performed analysis of Oct-4A expression in whole bone marrow, sorted VSEL population, as well as in single Lin-CD45-Sca1+ small cells. Embryonic stem cells (ESD3) were included as a positive control (Szade et al., 2013). When we used primers applied in the original study describing VSELs (Kucia et al., 2006), we detected the expected PCR product in embryonic stem cells, whole bone marrow and sorted VSEL population; however, this product was transcribed from a pseudogene template and appeared also if no reverse transcription was performed. Therefore, these primers cannot be used to determine the expression of Oct-4. Importantly, when we used other primers, specific to Oct-4A isoform, we detected Oct-4A only in ESD3 embryonic stem cells, but not in whole bone marrow, sorted VSEL population or single LinCD45-Sca1+ cells (Szade et al., 2013).

So what are VSELs? We demonstrated that the population gated as VSELs was enriched in the apoptotic, Annexin V positive cells. Moreover, even Annexin-V negative cells showed a high level of chromatin fragmentation (Szade et al., 2013). Interestingly, two months after our study the independent analysis by Irving Weissman's group from Stanford University, demonstrated that the events gated as VSELs are mainly the debris and fragmented cells with reduced DNA content (Miyanishi et al., 2013). In this study Miyanishi and co-workers additionally showed that VSELs did not display functional activity, did not form spheres or express Oct-4 and could not differentiate into blood cells upon transplantation into irradiated mice. The authors critically addressed technical issues connected with measuring size of cells by flow cytometry and used additional transgenic mouse models, like Oct4-EGFP and H2K-BCL-2 to verify the VSEL hypothesis. Furthermore, they even searched for pluripotent cells with less stringent gating on cell size and CD45 expression. However, all these attempts failed to confirm the existence of pluripotent VSELs what was in full agreement with our conclusions (Miyanishi et al., 2013).

Those studies (Szade et al., 2013; Miyanishi et al., 2013) are in line with results that undermined the properties of human umbilical cord blood-derived VSELs. The group of Rudiger Alt from Leipzig University demonstrated that the cord blood-derived Lin-CD45-VSELs lack the expression of CD34 and CD133 markers in contrast to original reports on human VSELs (Danova-Alt et al., 2012). Additionally, this study showed that VSELs do not express Oct-4, neither proliferate nor differentiate in vitro in variety of culture media, and have no markers of embryonic, neuronal, mesenchymal and hematopoietic stem cells (Danova-Alt et al., 2012). They also demonstrated that VSEL transcriptome is very much different from that of embryonic and adult stem cells and even of mature tissues, according to clustering analysis. The authors concluded that VSELs are dysfunctional, as this population is enriched in aneuploid cells (Danova-Alt et al., 2012).

Finally, the group of Alejandro Madrigal from Antony Nolan Research Institute in London has also shown that human umbilical cord blood population with Lin-CD45phenotype ascribed to VSELs is heterogeneous and negative for CD133. This group also was not able to culture Lin-CD45- cells under any of tested conditions and concluded that these cells lacked self-renewal capacity (Alvarez-Gonzalez et al., 2013). Thus, all these data indicate that also human VSELs are not the stem cells.

\section{METHODOLOGICAL STRINGENCY IN STEM CELL FIELD}

Could it be any scientific explanation for the results demonstrating pluripotent properties of VSELs? The studies about rare stem cell populations often involve cell sorting and it is important to understand the limitations of this technique, before generalized conclusions are stated. Long sorts, required to isolate number of rare populations, like VSELs, are never 100\% pure. Therefore, among sorted VSELs there could be few real HSC cells that can differentiate into the blood cells. This could be misleadingly interpreted as blood differentiation potential of VSEL population. The parallel to tomato juice, to which we put a drop of tabasco, can be illustrative. The juice is hot, not because of the tomato, but because of the drop of tabasco. So if in the tomato juice of so called VSELs there are few "tabasco drops" of real hematopoietic stem cells, they may give rise to different blood cells under appropriate conditions.

There are other, more probable than pluripotency, explanations of studies indicating broad plasticity of adult stem cells. Often, the conclusions are based solely on expression of markers, what cannot be considered clearly as a definite proof for pluripotency. In various cells types some of such marker genes are indeed expressed, but at the very low level, what also does not have any functional meaning (Kaltz et al., 2008). The expression of some genes can be the result of environmental in vitro conditions, which induce transcription of those genes, but do not induce pluripotency of those cells. Moreover, the used antibodies and primers might be not specific enough (Liedtke et al., 2008). Finally, the proof of the pluripotent or multipotent characteristic of the cells requires additional stringent tests like functional assays (chimera formation or blastocyst complementation and teratoma formation for pluripotent cells) (Jaenisch \& Young, 2008) together with the single cells assays of differentiation.

\section{“REPAIRING" HEART BY BONE MARROW}

Another story largely advertised in the field of regenerative medicine concerns the application of bone marrow cells for the treatment of myocardial infarction. In 2001 Pierro Anversa's group, then at Valhalla Medical College, published a paper demonstrating that bone marrow cells injected into the heart could differentiate into cardiomyocytes and improve cardiac function (Orlic et al., 2001). Soon after that the clinicians have started the clinical trials, in which the patients after myocardial infarction were treated with the injection of their own bone marrow cells (Strauer et al., 2002; Assmus et al., 2002; Perin et al., 2003; Stamm et al., 2003; Wollert et al., 2004). The clinical trials were initiated despite the fact that this experimental study has not been really confirmed by independent laboratories. The verification came three years later: Charles Murry group from Seattle (Murry et al., 2004), and two other groups, Balsam and Robins including Irving Weissman contribution (Balsam et al., 2004) and Nygren and co-workers (Nygren et al., 2004), also from the United States, showed that HSCs do not transdifferentiate into cardiomyocytes. Murry group used bone marrow from LacZ-expressing mice (Murry et al., 2004), the group of Balsam and Robins used GFP-expressing mice (Balsam et al., 2004). When they injected HSC into mice that underwent myocardial infarction, they did not observe any differentiation into cardiac myocytes. Injected cells simply differentiated into 
the blood cells (Balsam et al., 2004), or fused with the cardiac cells (Nygren et al., 2004). Any beneficial effect could not be thus ascribed to the differentiation potential of bone marrow cells.

Nevertheless, clinical trials have started despite the above concerns, mostly in Europe (Strauer et al., 2002; Assmus et al., 2002; Stamm et al., 2003; Wollert et al., 2004). The studies have been continued and not halted despite inconsistent results. Usually, the improvement of the LFEV was shown as a marker of the effectiveness of the BM-cell treatment. However, in some studies the LVEF was increased after BM cell injection by $5-10 \%$, while in other studies LVEF did not increase at all (Jong et al., 2014). The effects observed were usually transient. Reproducibly, the studies were in general safe and did not cause any harm to the patients. However, the validity of the trials performed by Strauer et al. (Strauer et al., 2002) has been questioned (Grens, 2015).

Recently, the group of Darrel Francis from Imperial College in London analyzed the performed clinical trials, in which BM cells were used for treatment of myocardial infarction (Nowbar et al., 2014). This analysis has revealed the interesting but alarming correlations. It has been shown that the more discrepancies of various types were found in the trial, the more effective therapy was claimed. In trials, in which Francis and coworkers did not find any mistakes, no improvements in LVEF were reported. However, the other trials where mistakes and inconsistencies were found, like untrue patient descriptions (e.g. dead patients reported as alive patients; lack of proper description of the number of patients with the given sex, etc.) demonstrated significant improvement in LVEF. Hence, the more errors were found in the trial, the better LVEF “improvement" was observed (Nowbar et al., 2014). In 133 reports from 49 trials more than 600 discrepancies were found, and, what is alarming, only five trials were found without errors. They showed no change in LEEV (Nowbar et al., 2014).

Various examples described above indicate that we are faced with a sort of never-ending story in the field of stem cell applications for regenerative medicine. Initially, animal studies provide feasibility for this approach. Such studies, performed usually in mice, show often a dramatic improvement in infarcted heart function after BM cell application. However later, the results are often not reproduced in studies in large animals, where only moderate improvement is observed. In clinical trials, in phase 1 there is a decent improvement, but phases 2 and 3 do not confirm any beneficial effects.

Despite these negative results and studies undermining the effectiveness of such therapies, once initiated, the clinical trials tend to thrive. Currently, the European Union has funded a new big clinical study called BAMI (clinicaltrial.gov, number: NCT01569178), that involves 3000 persons and costs 6 mln euro (Choudry \& Mathur, 2011). The aims stated are, once again, defined for resolving whether a mix of autologous bone marrow cells can help after myocardial infarction. In the opinion of some clinicians, this study is unethical, because it has been already shown that such approach did not work (Couzin-Frankel, 2014).

Importantly, negative data are often not acknowledged in the field of stem cells research. The researchers, whose works do not confirm the original "attractive" hypothesis are claimed to be wrong only because they did not confirm the properties on the "miracle stem cells" claimed to be the "Holy Grails", like was often stated for VSELs. People who present negative data are often attacked (see comments in: Abbott, 2013). Accordingly,
Charles Murry, whose work demonstrated that Dr. Anversa data are misleading, said: "I was struck by how little effect the negative results had on a field that was gathering momentum".

\section{HYPES IN PURSUIT FOR PLURIPOTENCY}

There is the most recent story, which illustrates very well what can happen when there are enormous hopes and expectations in the stem cell field. At the end of January 2014 two papers were published in Nature (Obokata et al., 2014c, 2014d) in which Japanese-American group reported that adult somatic cells, just by the brief exposure to the acidic conditions $(\mathrm{pH}$ 4.5) for 20 minutes, could be reprogrammed into the so-called STAP cells (STAP states for stimulus-triggered acquisition of pluripotency). They were claimed to contribute to embryo development similarly to the induced pluripotent stem cells (iPSCs) (Obokata et al., 2014c).

Moreover, investigators proposing the STAP hypothesis suggested that these cells could be reversed even to the totipotent state, as they were able in their hands to contribute both to embryo and placenta. The first author of those papers was Haruko Obokata from RIKEN institute in Kobe, and Yoshiki Sasai and Teruhiko Wakayama were among the senior authors. Charles Vacanti, mentioned already above, was an author in both studies, being a senior author in one of the papers.

As expected, such promising studies acquired a lot of attention and immediately many scientists wanted to reproduce them. Quickly it became clear that no one was able to confirm the study. A few weeks after the publication, Teruhiko Wakayama raised the alarm that he was not able to reproduce the experiment when he was working with the cells prepared by him, not with the cells that he got from Dr. Obokata. RIKEN institute immediately initiated the procedure very adequate to the situation: they started to investigate if the experiments were performed in accordance with scientific stringency. Already in the beginning of April 2014 RIKEN commission concluded that there were important inconsistencies and errors in these studies (Cyranoski, 2014a).

Haruko Obokata was accused of being responsible for unaccepted approach to research, but also the senior investigators were considered of not properly supervising the project. The publications have been finally withdrawn on the July 2nd 2014 (Cyranoski, 2014b). Nevertheless, Charles Vaccanti, who described so-called spore-like cells, was very much opposing that action (Normile \& Vogel, 2014). Dr. Vaccanti still claimed that STAP cells can be generated and he believes those cells exist in the body in the form of very small sporelike cells. The story has a very dramatic end. In August 2014, Yoshiki Sasai, a co-author of those withdrawn papers, a very talented developmental biologist with great scientific achievements committed suicide, leaving a letter to Haruko Obokata, asking her to repeat the results (Cyranoski, 2014c). In December 2014 RIKEN finally announced that the STAP cells cannot be reproduced, and it has been revealed that the cells used by Obokata were in fact the murine embryonic stem cells (Cyranoski, 2014d). Obokata was dismissed from her work in RIKEN. Dr. Vacanti, who is highly responsible for the reported problems, took a sabbatical from Harvard. It is not known if Harvard authorities are doing any investigations. 


\section{FUTURE OF STEM CELL THERAPY}

Despite these negative examples of research in stem cells, it should be underlined that stem cell therapies have already been proven to be successful. There are effective therapies based on the stem cells, such as hematopoietic bone marrow transplantation, skin regeneration from cultured progenitors or application of limbal stem cells for treatment of damaged cornea (Rama et al., 2010; Bianco et al., 2014). On the other hand, there are many other approaches, mostly not mentioned here, that had never been proved and with no evidence that they represented the action of the stem cells.

We have the real pluripotent stem cells, like human embryonic stem cells, which under appropriate conditions can differentiate into all cell types, and which can be potentially used for therapeutic purposes. Some clinical trials using ESC have been started (Schwartz et al., 2012). It is a justified hope that they can lead to the treatment. Finally, we can generate the iPSCs, obtained for the first time by Yamanaka and Takahashi (Takahashi \& Yamanaka, 2006), whose large potential was already demonstrated and validated by numerous independent investigators. iPSCs can be used not only for therapy but also for disease modeling and drug research.

Do we need the "Holy Grail" in the stem cell research and regenerative medicine? In fact, there is no convincing evidence for "Holy Grail" among adult stem cells. Adult stem cells like HSC and MSC, or satellite cells in the muscle and other tissue-specific stem cells have limited differentiation potential and they are not pluripotent. However, the multipotency or even unipotency of adult stem cells do not preclude their therapeutic application and are rather a favorable feature. The only limitation is that they should be applied in a tissue specific manner. However, we do not need to use the bone marrow for treatment of the cornea. We have corneal stem cells that can be applied for the treatment of the damaged eye.

It is a high responsibility of scientists and physicians not to make unjustified hope and not to generate hype on the properties and possible applications of any stem cells.

Therefore, for the sake of scientific purity and benefit of the patients we have to go back to the methodological rules established long time ago, but still valid. The so-called Ockham's razor principle has to be used in the field of stem cell research: "Pluralitas non est ponenda sine neccesitate" (attributed to William of Ockham, c. 1287 -1347; Spade \& Panacio, 2011) ("Entities should not be multiplied unnecessarily"). As the field of stem cells is filled with enormous expectations and, unfortunately, also numerous hypes, such a methodological stringency is of the highest importance.

\section{Acknowledgements}

We want to thank our colleagues in the Department of Medical Biotechnology for all their work and stimulating discussions. Faculty of Biochemistry, Biophysics and Biotechnology is beneficiary of National Research Leading Center (KNOW) grant from Polish Ministry for Science and Higher Education.

\section{Financial support}

The Department's research on stem cells is supported by grants from the National Science Center (MAESTRO 2012/06/A/NZ1/00004; HARMONIA 2014/14/M/ NZ1/00010, PRELUDIUM 2013/11/N/NZ3/00956 and $2013 / 11 / \mathrm{N} / \mathrm{NZ3} / 00958$ ) and National Centre for
Research and Development (POIG 01.02.00-069/09). The previous work of the authors on VSELs was supported by the POIG 01.02.01-109/09 grant.

\section{REFERENCES}

Abbott A (2013) Doubt cast over tiny stem cells. Nature 499: 390-390.

Alvarez-Dolado M, Pardal R, Garcia-Verdugo JM, Fike JR, Lee HO, Pfeffer K, Lois C, Morrison SJ, Alvarez-Buylla A (2003) Fusion of bone-marrow-derived cells with Purkinje neurons cardiomyocytes and hepatocytes. Nature 425: 968-973.

Alvarez-Gonzalez C, Duggleby R, Vagaska B, Querol S, Gomez SG, Ferretti P, Madrigal A (2013) Cord blood Lin(-)CD45(-) embryonic-like stem cells are a heterogeneous population that lack self-renewal capacity. PloS One 8: e67968.

Asahara T, Murohara T, Sullivan A, Silver M, van der Zee R, Li T, Witzenbichler B, Schatteman G, Isner JM (1997) Isolation of putative progenitor endothelial cells for angiogenesis. Science 275: 964-967.

Asahara T, Masuda H, Takahashi T, Kalka C, Pastore C, Silver M, Kearne M, Magner M, Isner JM (1999) Bone marrow origin of endothelial progenitor cells responsible for postnatal vasculogenesis in physiological and pathological neovascularization. Circ Res 85: 221-228.

Assmus B, Schächinger V, Teupe C, Britten M, Lehmann R, Döbert N, Grünwald F, Aicher A, Urbich C, Martin H, Hoelzer D, Dimmeler S, Zeiher AM (2002) Transplantation of progenitor cells and regeneration enhancement in acute myocardial infarction (TOPCARE-AMI) Circulation 106: 3009-3017.

Baker M (2007) Flawed data in multipotent cell study. Nat Rep Stem Cells doi:10.1038/stemcells.2007.40.

Balsam LB, Wagers AJ, Christensen JL, Kofidis T, Weissman IL, Robbins RC (2004) Haematopoietic stem cells adopt mature haematopoietic fates in ischaemic myocardium. Nature 428: 668673.

Bianco P (2014) "Mesenchymal" stem cells. Annu Rev Cell Dev Biol 30: 677-704

Bianco P, Barker R, Brüstle O, Cattaneo E, Clevers H, Daley GQ, De Luca M, Goldstein L, Lindvall O, Mummery C, Robey P.G, Sattler de Sousa E, Brito C, Smith A (2013) Regulation of stem cell therapies under attack in Europe: for whom the bell tolls. EMBO J 428: 1489-1495.

Bryder D, Rossi DJ, Weissman IL (2006) Hematopoietic stem cells: the paradigmatic tissue-specific stem cell. Am J Pathol 169: 338-346.

Bussolati B, Ahmed A, Pemberton H, Landis RC, Carlo FD, Haskard DO, Mason JC (2004) Bifunctional role for VEGF-induced heme oxygenase-1 in vivo: induction of angiogenesis and inhibition of leukocytic infiltration. Blood 103: 761-766.

Check E (2007) Stem cells: the hard copy. Nature 446: 485-486.

Chen J, Li Y, Wang L, Zhang Z, Lu D, Lu M, Chopp M (2001) Therapeutic Benefit of intravenous administration of bone marrow stromal cells after cerebral ischemia in rats. Stroke 32: 1005-1011.

Choudry FA, Mathur A (2011) Stem cell therapy in cardiology. Regen Med 6: 17-23.

Couzin-Frankel J (2014) The elusive heart fix. Science 345: 252-257.

Cyranoski D (2014a) Stem-cell scientist found guilty of misconduct. Nature doi:10.1038/nature.2014.14974.

Cyranoski D (2014b) Papers on "stress-induced" stem cells are retracted. Nature doi:10.1038/nature.2014.15501.

Cyranoski D (2014c) Stem-cell pioneer blamed media "bashing" in suicide note. Nature doi:10.1038/nature.2014.15715.

Cyranoski D (2014d) Still no stem cells via easy "STAP" path. Nature doi:10.1038/nature.2014.16606.

Dahl J-A, Duggal S, Coulston N, Millar D, Melki J, Shahdadfar A, Brinchmann JE, Collas P (2008) Genetic and epigenetic instability of human bone marrow mesenchymal stem cells expanded in autologous serum or fetal bovine serum. Int J Dev Biol. 52: 10331042 .

Danova-Alt R, Heider A, Egger D, Cross M, Alt R (2012) Very small embryonic-like stem cells purified from umbilical cord blood lack stem cell characteristics. Plos One 7: e34899.

Dawn B, Tiwari S, Kucia MJ, Zuba-Surma EK, Guo Y, Sanganalmath SK, Abdel-Latif A, Hunt G, Vincent RJ, Taher H, Reed NJ, Ratajczak MZ, Bolli R (2008) Transplantation of bone marrowderived very small embryonic-like stem cells attenuates left ventricular dysfunction and remodeling after myocardial infarction. Stem Cells Dayt. Ohio 26: 1646-1655.

Deramaudt BM, Braunstein S, Remy P, Abraham NG (1998) Gene transfer of human heme oxygenase into coronary endothelial cells potentially promotes angiogenesis I Cell Biochem. 68: 121-127.

Dulak J, Józkowicz A, Foresti R, Kasza A, Frick M, Huk I, Green C.J, Pachinger O, Weidinger F, Motterlini R (2002) Heme oxygenase activity modulates vascular endothelial growth factor synthesis in vascular smooth muscle cells. Antioxid Redox Signal 4: 229-240. 
Dulak J, Deshane J, Jozkowicz A, Agarwal A (2008) Heme oxygenase-1 and carbon monoxide in vascular pathobiology focus on angiogenesis. Circulation 117: 231-241.

Ferrari G, Cusella G, Angelis D, Coletta M, Paolucci E, Stornaiuolo A, Cossu G, Mavilio F (1998) Muscle regeneration by bone marrowderived myogenic progenitors. Science 279: 1528-1530.

Grens K (2015) Hearts on trial. The Scientist 29: 47-52.

Grochot-Przeczek A, Kotlinowski J, Kozakowska M, Starowicz K, Jagodzinska J, Stachurska A, Volger OL, Bukowska-Strakova K, Florczyk U, Tertil M, Jazwa A, Szade K, Stepniewski J, Loboda A, Horrevoets AJ, Dulak J, Jozkowicz A (2014) Heme oxygenase-1 is required for angiogenic function of bone marrow-derived progenitor cells: role in therapeutic revascularization. Antioxid Redox Signal 20: 1677-1692.

Hess D, Li L, Martin M, Sakano S, Hill D, Strutt B, Thyssen S, Gray DA, Bhatia M (2003) Bone marrow-derived stem cells initiate pancreatic regeneration. Nat Biotechnol 21: 763-770.

Huang Y, Kucia M, Hussain L.-R, Wen Y, Xu H, Yan J, Ratajczak MZ, Ildstad ST (2010) Bone marrow transplantation temporarily improves pancreatic function in streptozotocin-induced diabetes: potential involvement of very small embryonic-like cells. Transplantation 89: 677-685.

Jaenisch R, Young R (2008) Stem cells the molecular circuitry of pluripotency and nuclear reprogramming. Cell 132: 567-582.

Jiang Y, Jahagirdar BN, Reinhardt RL, Schwartz RE, Keene CD, Ortiz-Gonzalez XR, Reyes M, Lenvik T, Lund T, Blackstad M Du J, Aldrich S, Lisberg A, Low WC, Largaespada DA, Verfaillie CM (2002) Pluripotency of mesenchymal stem cells derived from adult marrow. Nature 418: 41-49.

Jong R de Houtgraaf JH, Samiei S, Boersma E, Duckers HJ (2014) Intracoronary stem cell infusion after acute myocardial infarction a meta-analysis and update on clinical trials. Circ Cardiovasc Interv 7: $156-167$.

Józkowicz A, Huk I, Nigisch A, Weigel G, Dietrich W, Motterlini R, Dulak J (2003) Heme oxygenase and angiogenic activity of endothelial cells: stimulation by carbon monoxide and inhibition by tin protoporphyrin-IX. Antioxid Redox Signal 5: 155-162.

Kale S, Karihaloo A, Clark PR, Kashgarian M, Krause DS, Cantley LG (2003) Bone marrow stem cells contribute to repair of the ischemically injured renal tubule. J Clin Invest 112: 42-49.

Kalka C, Masuda H, Takahashi T, Kalka-Moll WM, Silver M, Kearney M, Li T, Isner JM, Asahara T (2000) Transplantation of ex vivo expanded endothelial progenitor cells for therapeutic neovascularization. Proc Natl Acad Sci U S A 97: 3422-3427.

Kaltz N, Funari A, Hippauf S, Delorme B, Noël D, Riminucci M, Jacobs VR, Häupl T, Jorgensen C, Charbord P, Peschel C, BiancoP, Oostendordp RA (2008) In vivo osteoprogenitor potency of human stromal cells from different tissues does not correlate with expression of POU5F1 or its pseudogenes. Stem Cells Dayt. Ohio 26: 2419-2424.

Kamihata H, Matsubara H, Nishiue T, Fujiyama S, Tsutsumi Y, Ozono R, Masaki H, Mori Y, Iba O, Tateishi E, Kosaki A, Shintani S, Murohara T, Imaizumi T, Iwasaka T (2001) Implantation of bone marrow mononuclear cells into ischemic myocardium enhances collateral perfusion and regional function via side supply of angioblasts angiogenic ligands and cytokines. Circulation 104: 10461052.

Kataoka K, Medina RJ, Kageyama T, Miyazaki M, Yoshino T, Makino T, Huh N (2003) Participation of adult mouse bone marrow cells in reconstitution of skin. Am I Pathol 163: 1227-1231.

Knoepfler (2014) Interview with Charles Vacanti on STAP Cells: Link to Spore Stem Cells \& More. https://www.ipscell.com/2014/02/ interview-with-charles-vacanti-on-stap-cells-link-to-spore-stem-cellsmore/.

Kucia M, Reca R, Campbell FR, Zuba-Surma E, Majka M, Ratajczak J, Ratajczak MZ (2006) A population of very small embryonic-like (VSEL) CXCR4(+)SSEA-1(+)Oct-4+ stem cells identified in adult bone marrow. Leukemia 2:0 857-869.

Lakkisto P, Siren J-M, Kytö V, Forsten H, Laine M, Pulkki K, Tikkanen I (2011) Heme oxygenase-1 induction protects the heart and modulates cellular and extracellular remodelling after myocardial infarction in rats. Exp Biol Med 236: 1437-1448.

Li H, Fan X, Kovi R.C, Jo Y, Moquin B, Konz R, Stoicov C, KurtJones E, Grossman SR, Lyle S, Rogers AB, Montrose M, Houghton J (2007) Spontaneous expression of embryonic factors and p53 point mutations in aged mesenchymal stem cells: a model of agerelated tumorigenesis in mice. Cancer Res 67: 10889-10898.

Liedtke S, Enczmann J, Waclawczyk S, Wernet P, Kögler G (2007) Oct4 and its pseudogenes confuse stem cell research. Cell Stem Cell 1: 364-366.

Liedtke S, Stephan M, Kögler G (2008) Oct4 expression revisited: potential pitfalls for data misinterpretation in stem cell research. Biol Chem 389: 845-850.

Mezey É, Chandross KJ, Harta G, Maki RA, McKercher SR (2000) Turning blood into brain: cells bearing neuronal antigens generated in vivo from bone marrow. Science 290: 1779-1782.
Miyanishi M, Mori Y, Seita J, Chen JY, Karten S, Chan CKF, Nakauchi H, Weissman IL (2013) Do pluripotent stem cells exist in adult mice as very small embryonic stem cells? Stem Cell Rep 1: 198-208.

Müller F-J, Goldmann J, Löser P, Loring JF (2010) A call to standardize teratoma assays used to define human pluripotent cell lines. Cell Stem Cell 6: 412-414.

Murry E, Soonpaa MH, Reinecke H, Nakajima H, Nakajima HO, Rubart M, Pasumarthi KBS, Ismail Virag J, Bartelmez SH, Poppa V, Bradford G, Dowell JD, Williams DA, Field LJ (2004) Haematopoietic stem cells do not transdifferentiate into cardiac myocytes in myocardial infarcts. Nature 428: 664-668.

Normile D, Vogel G (2014) Irreproducibility dogs new reprogramming method. Science 343: 1299-1300.

Nowbar AN, Mielewczik M, Karavassilis M, Dehbi H-M, Shun-Shin MJ, Jones S, Howard JP, Cole GD, Francis DP (2014) Discrepancies in autologous bone marrow stem cell trials and enhancement of ejection fraction (DAMASCENE): weighted regression and metaanalysis. BMJ 348: g2688.

Nygren JM, Jovinge S, Breitbach M, Säwén P, Röll W, Hescheler J, Taneera J, Fleischmann BK, Jacobsen SEW (2004) Bone marrowderived hematopoietic cells generate cardiomyocytes at a low frequency through cell fusion but not transdifferentiation. Nat Med 10: $494-501$.

Obokata H, Wakayama T, Sasai Y, Kojima K, Vacanti MP, Niwa H, Yamato M, Vacanti CA (2014a) Retraction: Stimulus-triggered fate conversion of somatic cells into pluripotency. Nature 511: 112-112.

Obokata H, Sasai Y, Niwa H, Kadota M, Andrabi M, Takata N, Tokoro M, Terashita Y, Yonemura S, Vacanti CA, Wakayama $\mathrm{T}$ (2014b) Retraction: Bidirectional developmental potential in reprogrammed cells with acquired pluripotency. Nature 511: 112112.

Obokata H, Wakayama T, Sasai Y, Kojima K, Vacanti MP, Niwa H, Yamato M, Vacanti CA (2014c) Stimulus-triggered fate conversion of somatic cells into pluripotency. Nature 505: 641-647.

Obokata H, Sasai Y, Niwa H, Kadota M, Andrabi M, Takata N, Tokoro M, Terashita Y, Yonemura S, Vacanti CA, Wakayama T (2014d) Bidirectional developmental potential in reprogrammed cells with acquired pluripotency. Nature 505: 676-680.

Orlic D, Kajstura J, Chimenti S, Jakoniuk I, Anderson SM, Li B, Pickel J, McKay R, Nadal-Ginard B, Bodine DM, Leri A, Anversa P (2001) Bone marrow cells regenerate infarcted myocardium. Nature 410: 701-705.

Perin EC, Dohmann HFR, Borojevic R, Silva SA, Sousa ALS, Mesquita CT, Rossi MID, Carvalho AC, Dutra HS, Dohmann HJF, Silva GV, Belem L, Vivacqua R, Rangel FO, Esporcatte R, Geng YJ, Vaughn WK, Assad JA, Mesquita ET, Willerson JT (2003) Transendocardial autologous bone marrow cell transplantation for severe chronic ischemic heart failure. Circulation 107: 2294-2302.

Petersen BE, Bowen WC, Patrene KD, Mars WM, Sullivan AK, Murase N, Boggs SS, Greenberger JS, Goff JP (1999) Bone marrow as a potential source of hepatic oval cells. Science 284: 1168-1170.

Phinney DG, Prockop DJ (2007) Concise review: mesenchymal stem/ multipotent stromal cells: the state of transdifferentiation and modes of tissue repair — current views. Stem Cells 25: 2896-2902.

Rama P, Matuska S, Paganoni G, Spinelli A, De Luca M, Pellegrini G (2010) Limbal stem-cell therapy and long-term corneal regeneration. N Engl J Med 363: 147-155.

Ratajczak J, Zuba-Surma E, Paczkowska E, Kucia M, Nowacki P, Ratajczak MZ (2011a) Stem cells for neural regeneration - a potential application of very small embryonic-like stem cells. $J$ Pol Physiol Soc 62: 3-12.

Ratajczak J, Wysoczynski M, Zuba-Surma E, Wan W, Kucia M, Yoder MC, Ratajczak MZ (2011b) Adult murine bone marrowderived very small embryonic-like stem cells differentiate into the hematopoietic lineage after coculture over OP9 stromal cells. Exp Hematol 39: 225-237.

Schwartz SD, Hubschman J-P, Heilwell G, Franco-Cardenas V, Pan CK, Ostrick RM, Mickunas E, Gay R, Klimanskaya I, Lanza R (2012) Embryonic stem cell trials for macular degeneration: a preliminary report. The Lancet 379: 713-720.

Spade PV Panaccio C (2011) William of Ockham. The Stanford Encyclopedia of Philosophy (Fall 2011 Edition) Zalta EN ed. Stanford Stanford University URL =http://plato.stanford.edu/archives/ fall2011/entries/ockham/ (accessed March 26 2015).

Stamm C, Westphal B, Kleine H-D, Petzsch M, Kittner C, Klinge H, Schümichen C, Nienaber CA, Freund M, Steinhoff G (2003) Autologous bone-marrow stem-cell transplantation for myocardial regeneration. The Lancet 361: 45-46.

Strauer BE, Brehm M, Zeus T, Köstering M, Hernandez A, Sorg RV, Kögler G, Wernet P (2002) Repair of infarcted myocardium by autologous intracoronary mononuclear bone marrow cell transplantation in humans. Circulation 106: 1913-1918.

Szade K, Zuba-Surma E, Rutkowsk AJ, Jozkowicz A, Dulak J (2011) CD45-CD14+CD34+ Murine bone marrow low-adherent mesenchymal primitive cells preserve multilineage differentiation potential in long-term in vitro culture. Mol Cells 31: 497-507. 
Szade K, Bukowska-Strakova K, Nowak WN, Szade A, KachamakovaTrojanowska N, Zukowska M, Jozkowicz A, Dulak J (2013) Murine bone marrow Lin-Sca-1+CD45- very small embryonic-like (VSEL) cells are heterogeneous population lacking Oct-4A expression. PloS One 8: e63329.

Takahashi K, Yamanaka S (2006) Induction of pluripotent stem cells from mouse embryonic and adult fibroblast cultures by defined factors. Cell 126: 663-676.

Tang YL, Tang Y, Zhang YC, Qian K, Shen L, Phillips MI (2005) Improved graft mesenchymal stem cell survival in ischemic heart with a hypoxia-regulated heme oxygenase-1 vector. I Am Coll Cardiol 46: $1339-1350$.

Terada N, Hamazaki T, Oka M, Hoki M, Mastalerz DM, Nakano Y, Meyer EM, Morel L, Petersen BE, Scott EW (2002) Bone marrow cells adopt the phenotype of other cells by spontaneous cell fusion. Nature 416: 542-545.

Tolar J, Nauta AJ, Osborn MJ, Panoskaltsis Mortari A, McElmurry RT, Bell S, Xia L, Zhou N, Riddle M, Schroeder TM, Westendorf JJ, McIvor RS, Hogendoorn PC, Szuhai K, Oseth L, Hirsch B, Yant SR, Kay MA, Peister A, Prockop DJ, Fibbe WE, Blazar BR (2007) Sarcoma derived from cultured mesenchymal stem cells. Stem Cells Dayt. Ohio 25: 371-379.

Vacanti MP, Roy A, Cortiella J, Bonassar L, Vacanti CA (2001) Identification and initial characterization of spore-like cells in adult mammals. I Cell Biochem 80: 455-460.

Wagers AJ, Weissman IL (2004) Plasticity of adult stem cells. Cell 116: 639-648.
Wang X, Willenbring H, Akkari Y, Torimaru Y, Foster M, Al-Dhalimy M, Lagasse E, Finegold M, Olson S, Grompe M (2003) Cell fusion is the principal source of bone-marrow-derived hepatocytes. Nature 422: 897-901.

Weissman IL (2000) Stem cells: units of development units of regeneration and units in evolution. Cell 100: 157-168.

Wojakowski W, Tendera M, Cybulski W, Zuba-Surma E.K, Szade K, Florczyk U, Kozakowska M, Szymula A, Krzych L, Paslawska U, Paslawski R, Milewski K, Buszman PP, Nabialek E, Kuczmik W, Janiszewski A, Dziegiel P, Buszman PE, Jozkowicz A, Dulak J (2012) Effects of intracoronary delivery of allogenic bone marrowderived stem cells expressing heme oxygenase-1 on myocardial reperfusion injury. Thromb Haemost 108: 464-475

Wollert KC, Meyer GP, Lotz J, Ringes Lichtenberg S, Lippolt P, Breidenbach C, Fichtner S, Korte T, Hornig B, Messinger D, Arseniev L, Herstenstein B, Ganser A, Drexler H (2004) Intracoronary autologous bone-marrow cell transfer after myocardial infarction: the BOOST randomised controlled clinical trial. The Lancet 364: 141-148.

Zuba-Surma EK, Kucia M, Ratajczak J, Ratajczak MZ (2009) "Small Stem Cells" in adult tissues: very small embryonic-like stem cells (VSELs) stand up! Cytom. Part J Int Soc Anal Cytol 75: 4-13. 